\title{
El ciberactivismo, nueva forma de movilización social en la campaña del boicot comercial en Marruecos
}

\section{Cyberactivism, a new form of social mobilization in the commercial boycott campaign in Morocco}

\author{
Dra. Nasma Irakrak \\ Universidad de Sevilla (US) | Calle Américo Vespucio, 27, 41092 Sevilla | España | \\ ORCID: https://orcid.org/0000-0003-0886-2265| nasma.irakrak@gmail.com
}

Fechas | Recepción: 13/10/2020 | Aceptación: 30/11/2020

\section{Resumen}

La campaña del boicot comercial en Marruecos ha dado lugar a una realidad en la que la tecnología y el activismo se han dado la mano para crear una estrategia de movilización social exitosa. El reclamo de la sociedad utilizó las nuevas tecnologías para, de forma inédita, producir un boicot comercial sustentado únicamente en el ciberactivismo. De esta forma se hicieron visibles los indicios de un cambio social latente y de una implicación comunitaria y tecnológica considerable surgidos a través de la llamada "Primavera Árabe". En el presente artículo se analizan las prácticas tecno comunicativas efectuadas durante la campaña del boicot comercial en Marruecos, conocidas como «\#moqatioune (boicoteamos)» que pretendió movilizar a la población marroquí llamándola a participar e implicarse en dicha campaña.

Para llevar a cabo este estudio se ha adoptado una metodología cuantitativa del análisis del contenido. De esta manera se ha estudiado el elemento tecno comunicativo, la narrativa expuesta y la interacción continua de mensajes, potenciados por el poder de las nuevas tecnologías, especialmente la red social Facebook, durante la campaña del boicot

\section{Abstract}

The commercial boycott campaign in Morocco has led to a reality in which technology and activism have come together to create a successful social mobilization strategy. The claim of society used new technologies to, in an unprecedented way, produce a commercial boycott based solely on cyberactivism. In this way, the signs of latent social change and considerable community and technological involvement emerged through the so-called "Arab Spring" became visible. This article analyzes the techno-communicative practices carried out during the commercial boycott campaign in Morocco, known as "\#moqatioune (we boycott)" that sought to mobilize the Moroccan population by calling them to participate and get involved in said campaign.

To carry out this study, a quantitative content analysis methodology has been adopted. In this way, the techno-communicative element, the exposed narrative and the continuous interaction of messages, enhanced by the power of new technologies, especially the social network Facebook, have been studied during the commercial boycott campaign. The main results of this study have shown that the success of the campaign is fundamentally due to the 
comercial. Los resultados principales de este estudio han demostrado que el éxito de la campaña se debe fundamentalmente a la eficacia de las estrategias de movilización. El uso de las nuevas tecnologías de la comunicación, han demostrado ser un instrumento poderoso para expandir la información, visibilizar, influir y convocar las protestas.

Palabras clave: ciberactivismo, prácticas tecno comunicativas, boicot, cambio social, movilización social. effectiveness of the mobilization strategies. The use of new communication technologies has proven to be a powerful instrument to spread information, make visible, and influence and call protests.

Keywords: cyberactivism, technocommunicative practices, boycott, social change, social mobilization.

\section{INTRODUCCIÓN}

Desde los comienzos de la denominada «Primavera Árabe», en 2011, el mundo árabe ya había quebrado la barrera del silencio al alzar la voz ante la injusticia social, económica, política y adquirir, asimismo, nuevas formas de movilización y de protesta.

El ciberactivismo es una de las estrategias que han florecido de manera destacada en estos países donde la libertad de expresión es limitada. De hecho, la censura y la desinformación son herramientas poderosas que han sido manejadas sutilmente por los regímenes árabes ante cualquier movilización social. Por tanto, con la aparición y la evolución de las nuevas tecnologías de la información y de la comunicación, las TIC, se ha dado un giro esencial en el ámbito de estas, al ofrecer más margen a la libertad de expresión y de información.

Esta revolución tecnológica de la comunicación se ha convertido en un arma eficaz para eludir el control tradicional de los poderes dominantes. Por ello, el tecno-activismo constituyó la mejor opción de los indignados para organizarse, expresarse y difundir sus mensajes. Este hecho se dio en Marruecos recientemente donde se han producido distintas movilizaciones y protestas tecno-políticas que han marcado la historia sociopolítica del país. En concreto resaltamos el Movimiento Popular del Rif, conocido por Hirak el Rif (octubre de 2016), la de los mineros de Yerada (diciembre de 2017) y la campaña del boicot comercial (abril de 2018).

En este sentido, la campaña objeto de estudio constituye una movilización tecno-política producida en Marruecos que pretendió boicotear los productos de tres marcas emblemáticas: los lácteos (Central Laitière), agua mineral (Sidi Ali) y gasolina (Afriquia, del grupo Akwa), que forman parte del conglomerado industrial del país.

A modo de aclaración: los productos boicoteados son de las empresas que forman parte del poder económico nacional, cuyos propietarios ostentan el máximo poder político y económico: el ministro de Agricultura y Pesca, Aziz Ajanuch de Afriquia, del Grupo Akwa, el principal distribuidor de combustible de Marruecos; Meriem Bensaleh Benchakrun, presidenta de la patronal marroquí agua mineral Sidi Ali, del gigante marroquí Holmarcom, propiedad de la misma familia; y por último, los lácteos, que pertenecen al grupo francés Centrale Danone.

Las desigualdades sociales y las injusticias experimentadas por el pueblo marroquí dieron lugar a que los indignados se refugiaran en el ciberespacio, concebido como una herramienta potente de participación sociopolítica mediante la cual se denunciaba la carestía de la vida y se desvelaba la realidad socioeconómica existente en Marruecos. A partir de mensajes informativos producidos por ciudadanos anónimos y divulgados en la red social, se expandió la campaña de boicot con la meta de que se produjeran pérdidas económicas y por consiguiente bajaran los precios de productos de primera necesidad. Dicha campaña ha sido producida y 
difundida a través de las redes sociales y, al mismo tiempo, silenciada por los medios de comunicación del país.

A partir de estas premisas y dado al papel primordial que ejercieron las redes sociales a la hora de organizar, convocar, expandir información e influir para llevar a cabo la campaña del boicot "\#moqatioune (boicoteamos)», intentaremos a través de este estudio realizar un análisis de contenido cuantitativo riguroso de las publicaciones de determinados grupos de la red social Facebook.

El principal objetivo de este estudio es analizar las prácticas tecno-comunicativas producidas durante la campaña del boicot comercial. A partir de ahí, los objetivos específicos que pretendemos alcanzar son: 1 ) medir el impacto de la campaña del boicot comercial a través de la interacción tecno-comunicativa, en especial en Facebook. 2) Analizar la clasificación temática y los mensajes dominantes de nuestro corpus analítico.

Las hipótesis de partida en que se basa este estudio son las siguientes:

1. Las TIC son un soporte instrumental poderoso que potencia nuevas formas de participación social y política.

2. Las redes sociales, en este caso Facebook, se usaron en la campaña del boicot comercial, como un instrumento para expandir la información, visibilizar, influir y convocar las protestas.

Para poder llevar a cabo el presente estudio se han seleccionado de manera aleatoria 150 publicaciones de los grupos de Facebook relacionados con la campaña del boicot comercial, del 20 de abril hasta finales de agosto del 2018, periodo de inicio y desarrollo de la campaña, un hecho sin precedentes en el mundo árabe. El artículo está estructurado en dos partes: un primer acercamiento al marco teórico contextual que ilumina los fundamentos necesarios, como el ciberactivismo y su papel en el cambio social. En este apartado observaremos el desarrollo de las movilizaciones sociales en Marruecos, su organización y la participación ciudadana, y la campaña del boicot comercial como un modelo de cambio social latente. Después de abarcar el marco teórico, abordaremos el alcance de la investigación a través de la metodología del análisis de contenido (Kripendorff), que aplicaremos en este estudio. Para cerrar ambas partes, los resultados se muestran en una serie de gráficos, seguidos de resultados generales y conclusiones.

\section{MARCO TEÓRICO-CONTEXTUAL}

\subsection{El ciberactivismo: nuevo poder para el cambio social}

La aparición de las TIC en el siglo XXI, como un conjunto convergente de tecnología de la microelectrónica, la informática, las telecomunicaciones y la optoelectrónica (Castells, 2000), se considera una auténtica revolución que se ha reflejado últimamente en el cambio social que se estaba produciendo de manera latente y detonante en el mundo. Así mismo, se ha manifestado dicha revolución en las formas de adquirir y manejar el conocimiento. A esa sociedad de cambio la denomina Castells (2000) como «sociedad red».

El poderoso uso de este medio, cuyo número de usuarios cada vez asciende y se extiende más, convierte a estas personas en partícipes y actores en la producción de la información y del cambio (Flores y Arruti, 2010). Con la irrupción de la web 2.0, que influye de una manera u otra en la sociedad árabe, sus miembros acceden constantemente a enormes cantidades de información y de conocimiento que repercuten sobre su comportamiento y acciones. En este marco, el ciberespacio ha adquirido un papel fundamental en la construcción de la opinión pública, influye en los usuarios y propicia el surgimiento del ciberactivismo que convoca y 
organiza sin barreras las movilizaciones sociales. Este ciberactivismo ha contribuido a la aparición de la comunidad digital, «comunidades insurgentes instantáneas» (Castells, 2009, p. 472), que transmite, intercambia y produce información, y difunde contenido ante un amplísimo público. Y de ahí proviene su poder de repercusión en la opinión pública. Es decir, estamos frente a usuarios de la red que ya son los protagonistas de los flujos comunicativos. La comunicación participativa debe ser observada como una lógica de constitución de la multiplicidad y autonomía social. Más que el proceso de apropiación y reconfiguración de la llamada esfera pública, se antoja, a nuestro juicio, más significativas las nuevas articulaciones comunitarias. En este sentido, el ciberactivismo es una suerte de recomposición y ensamblaje de la economía moral de la multitud (Sierra Caballero, 2020).

Así pues, la libertad de expresión sin precedentes que permite el ciberespacio ha contribuido al cambio social producido en los últimos años en el mundo árabe. Es cierto que el ciberactivismo no es el único factor que ha favorecido el cambio en estos países, pues existe toda una voluntad común del ciudadano indignado, que lleva años anhelando una oportunidad de expresarse libremente, sin miedo a represalias y sin hacer uso de los medios de comunicación convencionales, que, por otra parte, no les ofrecen cobertura, ni una información fidedigna y acorde a sus demandas.

En este sentido las redes sociales han facilitado las movilizaciones sociales y se han convertido en el medio más eficaz para reclamar cambios y expresar sus quejas. De hecho, el mundo árabe las ha utilizado como una herramienta política crítica y de denuncia, una herramienta eficaz de difusión y expansión de información, un soporte que trasmite la voz del pueblo, que pone en público todas las atrocidades e injusticias políticas, económicas y sociales que se viven en estos países. Las TIC son, sin lugar a duda, un soporte eficaz para las reivindicaciones ciudadanas con respecto a la esfera pública. Y, sobre todo, los medios sociales como Facebook y Twitter que "han sido claves para potenciar la participación ciudadana" (Lunt et al., 2013) y "han contribuido a modificar las formas de consumir y difundir la información" (FernandezPlanells y Linares, 2015).

En este mismo marco, cabe destacar que en la Primavera Árabe, fenómeno que ha dado un giro al mundo árabe tal y como se conocía hasta ese momento, sobre todo tras la caída de algunos regímenes dictatoriales, las redes sociales, como Twitter y Facebook, fueron líderes de dichas revueltas (Carrión, 2014), pues a partir de finales de 2010 aumentó el uso de ellas en esos países. Fueron utilizadas por los ciudadanos de Túnez, Egipto y Libia, y llegaron incluso a Siria y Yemen, con el fin de comunicar e interactuar sobre la realidad del mundo árabe y expresar libremente su indignación y su inquietud por la situación de sus respectivos países.

En efecto, nadie puede negar el papel de las redes sociales en los países en los que se propició la Primavera Árabe, ni tampoco la herencia reivindicativa que han dejado en la memoria colectiva del mundo árabe. Esas redes fueron consideradas como un enlace entre los acontecimientos que ocurrían en la calle y la información libre que se transmitía. Sin embargo, en los medios de comunicación oficiales se intentó minimizar lo que estaba ocurriendo en realidad en las calles al ignorar las movilizaciones populares como si no estuvieran ocurriendo en la vida real. Por eso, las redes sociales desde la Primavera Árabe han sido un actor y un estímulo para los cambios políticos y sociales y así mismo tuvieron un papel de suma importancia en los diversos movimientos de protesta en el mundo (Espiritusanto y Rodríguez, 2011).

Evidentemente las redes sociales han contribuido al cambio en el mundo árabe, han creado vínculos entre diferentes personas de distintas posiciones sociales, económicas y culturales sin tomar a priori en consideración la religión, la edad o la raza. Es decir, "las redes sociales desarrolladas gracias a la comunicación digital interactiva poseen un enorme potencial para 
facilitar las relaciones multiculturales. La idea original de las redes sociales enlaza con la base filosófica y política del multiculturalismo, sobre todo a través de las interacciones e intercambios directos a nivel local y global“ (Ji Young, 2015, p. 36). Por tanto, dichas redes han convertido al usuario en un actor efectivo y participativo que puede tener acceso en cualquier momento a cualquier información.

La ciudadanía pasa necesariamente por las posibilidades que le ofrece el ciberespacio a los sujetos para discutir sobre los derechos ciudadanos, para empoderar a las personas y ampliar el debate y la deliberación. Se trata de un ciudadano con un marco de acción más complejo, que tiene a su disposición espacios y herramientas desde las cuales acceder a la información, compartirla y generar procesos de deliberación. Ahora bien, el hecho que el ciberespacio sea considerado como el lugar por excelencia para deliberar y ejercer la ciudadanía, se debe en nuestro contexto de estudio, por las restricciones gubernamentales dirigidas a la esfera pública en los espacios físicos, en los cuales los ciudadanos no pueden exponer libremente sus opiniones y pensamientos en distintas comunidades políticas (Edixela Burgos, 2020).

\subsection{El desarrollo de las movilizaciones sociales en Marruecos: organización y participación ciudadana}

En la historia contemporánea del mundo árabe, el episodio que ha puesto de manifiesto en mayor medida el poder y la influencia de las nuevas tecnologías de la información y de la comunicación sobre la sociedad ha sido el de la Primavera Árabe (Tascón y Quintana, 2012). La circulación horizontal de la información entre los ciudadanos árabes y su inmediatez sirvieron de manera efectiva para la expansión y el contagio de las revueltas en estos países, y contribuyeron al denominado "efecto llamada», como subraya el investigador Xosé Soengas:

[...] El efecto mimético, desarrollado a partir de los primeros testimonios internacionales de solidaridad, que se transformó en un fenómeno masivo como consecuencia de la capacidad de convocatoria de la Red y del efecto llamada o efecto imitación. $Y$ esto provocó que las adhesiones fueran aumentando progresivamente desde el inicio. (2013, p.150)

En este marco cabe recordar la inmolación de Mohamed Bouzzizi, que fue grabada y difundida por YouTube entre miles de internautas. A raíz de este hecho, se convocaron manifestaciones a través de los dispositivos móviles y las redes sociales que condujeron, en última instancia, al derrocamiento de los regímenes autoritarios.

En el mismo periodo, un hecho aislado similar aconteció en Marruecos cuando un joven se prendió fuego y murió. Este acontecimiento, entre otros, tuvo como respuesta la aparición del "Movimiento 20 de febrero de 2011 ». En tan solo un mes, surgieron protestas ciudadanas cuyas reivindicaciones eran la dignidad, la igualdad y el fin de la corrupción y a través de las redes sociales se reclamaron reformas constitucionales y democráticas. Se ha hecho viral un video publicado en las redes sociales en el que aparecían quince jóvenes marroquíes que explicaban la situación de injusticia que sufre el pueblo marroquí y, al mismo tiempo, reclamaban una sociedad democrática. El video arrasó en las redes sociales y en YouTube, ya que "durante 2011, Facebook contaba con 3.905.980 usuarios marroquíes, con una tasa de penetración del 11,92 \%, superior a la media del 10\% de la región árabe (VV. AA., 2011b: 12 16), mientras que a finales de 2012 la cifra excedió los cinco millones" (Benítez-Eyzaguirre, 2015) [sic].

El ciberactivismo ha conocido un auge de participación ciudadana desde la Primavera Árabe, pues las redes sociales se han visto inundadas de fotografías, imágenes y videos grabados con teléfono móvil, en los que se denunciaba cualquier acto de violencia o injusticia. Se logró un éxito evidente del ciberactivismo tras la respuesta del Gobierno que culminó con las reformas constitucionales (Parejo Fernández, 2015). Estas movilizaciones pasaron del ciberespacio a los espacios públicos. Los ciberactivistas organizaban las convocatorias, difundían información, 
gestionaban su presencia en plazas, denunciaban en público cualquier represalia para que la comunicación interactiva cobrara una dimensión internacional (Buamama y Khaira, 2015).

Otro acto de movilización social en Marruecos se produjo tras la trágica muerte de un joven vendedor de pescado, Mouhcine Fikri, en Alhucema el 28 de octubre 2016. Las fotos de su macabra muerte, triturado en un camión de recogida de basura, se han hecho virales en las redes sociales. El impactante suceso tuvo como consecuencia la creación del Movimiento Popular del Rif, conocido por El Hirak El Rif, que exigía la clarificación de las circunstancias de la muerte del joven y, así mismo, justicia y castigo para los culpables de la tragedia (Ouled, 2018). Ese movimiento al poco tiempo de su surgimiento derivó a reivindicaciones sociales y económicas. Lo que se presentó como un accidente aislado se convirtió en el detonante de unas fuertes movilizaciones sociales que duraron casi ocho meses.

En este caso, no solo apareció el vil asesinato, sino también el enfrentamiento que tuvo el joven muerto con las autoridades que querían tirar su mercancía a la basura. En el ciberespacio se han hecho virales, imágenes y videos del joven asesinado dentro de un basurero, imágenes impactantes que contenían, en su mayoría, una frase clave: "Than Mou» (tritura a su madre) (Otman, 2016). Se trata de una expresión pronunciada por las autoridades con total desprecio al ciudadano que fue compartida numerosas veces por los internautas y publicada en las redes sociales y que ha servido para conmover a todo el pueblo marroquí.

Así que, gracias a la circulación de videos como el de la inmolación de Bouazzizi, a las imágenes macabras de la muerte Mouhsni Fikri, que, por supuesto, conmovió no solo a los países árabes, sino al mundo entero, y también a los videos que reflejaban la brutalidad de la represión sobre los manifestantes y a los de las masacres producidas por las autoridades, entre otras imágenes, se han podido dar a conocer las atrocidades cometidas.

En este marco, la siguiente movilización social objeto de estudio es la campaña del boicot comercial que dio comienzo el 20 de abril del 2018 y que se produjo a partir de la iniciativa de un grupo de Facebook titulado «\#moqatioune (boicoteamos)». Esos ciberactivistas pretendían un cambio económico al luchar en contra de los altos precios de productos esenciales del mercado nacional del país, productos como los lácteos (Central Laitiére), el agua mineral (Sidi Ali) y la gasolina (Afriquia) que son productos de gran demanda y primera necesidad.

La realidad de esta campaña refleja la conciencia del pueblo marroquí por la forma en que ha optado para protestar en contra de las desigualdades sociales. Esta manera de indignación no ha surgido espontáneamente, sino que es el resultado de las movilizaciones sociales anteriormente mencionadas, en las que la mayoría ya había sufrido persecuciones y represalias con la salida al espacio público de sus líderes, como sucedió en El Hirak del Rif con Nacer Zafzafi, entre otros ciberactivistas que terminaron en la cárcel. Por eso, la campaña del boicot se caracterizó por el anonimato de los ciberactivistas que influyeron en la opinión pública (Masbah, 2018). Se especulaba que era obra de los militantes del Partido de la Justicia y el Desarrollo de Marruecos, en un ajuste político contra el ministro de Agricultura y Pesca, Aziz Akhanouch, que es el magnate propietario del Grupo Akwa, cuyo producto fue boicoteado. Es uno de los hombres más poderosos del país, "considerado por la revista Forbes como el tercer hombre más rico de Marruecos, con un capital valorado en 1.400 millones de euros, después del rey Mohamed VI (5.300 millones) y del banquero Othman Benjelloun (1.700)" (Peregil, 2017). Otros especulaban que el surgimiento de la campaña provenía de la mera indignación del pueblo por las desigualdades sociales y la carestía de la vida.

La campaña ha sido calificada de efectiva y exitosa (Zairig, 2018), pues ha conseguido altos resultados sin salir a la calle ni entrar en enfrentamiento directos con las autoridades y ha demostrado la madurez del pueblo, su civismo y su apego a las nociones de democracia y también de respeto a la Constitución. El éxito de la campaña se ha visto reflejado además en las pérdidas económicas que sufrieron dichas empresas: 
[...] El boicot les supondrá una disminución de alrededor del $20 \%$ de su facturación y una pérdida neta de 150 millones de dirhams (13,5 millones de euros) en la primera mitad de 2018. Lo que se traduce, según el director general, Didier Lamblin, en una caída del 50 \% en las ventas en comparación con las mismas seis semanas de abril y mayo de 2017. (De la Cal, 2018, p. 1)

En general, el boicot es un acto político en su fondo, mediante el cual los ciudadanos expresan su descontento con la carestía de la vida y, sobre todo, contra una casta que monopoliza todos los sectores. Esa casta, cercana al poder político y que aúna las decisiones políticas con los intereses económicos, está constituida por inversores que, al mismo tiempo, presiden partidos políticos y dominan las instituciones legislativas que proclaman leyes a su favor y paralizan a un tiempo las instituciones de control del mercado. En Marruecos las prácticas económicas se han caracterizado por la dominación, y el boicot no es nada más que el fruto de una maduración socio-cognitiva del pueblo hacia la injusta realidad económica y política del país.

\subsection{Campaña del boicot comercial: cambio sociopolítico latente}

La campaña del boicot comercial, que se extendió el domingo 20 de abril de 2018 por la red social Facebook contra la carestía de la vida y las desigualdades sociales en Marruecos, se considera una forma de movilización sutil por parte del pueblo para expresar su indignación acerca de la situación económica del país. Los ciberactivistas han podido construir un espacio digital de difusión y de concienciación de la población. El espacio digital se presenta como una nueva forma de acción política, ya que a través de las páginas de Facebook los ciberactivistas mantenían continuamente informados a sus seguidores (Espiritusanto y Gonzalo Rodríguez, 2011).

Así pues, bajo el lema de "boicoteamos» y "déjala que se agrie», se hizo un llamamiento al boicot de los productos más consumidos en Marruecos, que se hizo viral en el país.

La leche Centrale, (perteneciente en un $91 \%$ a Danone, un 5\% al consorcio industrial del rey Mohamed VI y el otro $4 \%$ a pequeños accionistas) y el agua Sidi Ali, propiedad del grupo de la familia de Miriem Bensalah-Chaqroun, presidenta de la patronal marroquí (...), estaciones de servicio Afriquia, perteneciente al ministro de Agricultura y Pesca, Aziz Ajanuch, amigo íntimo del rey y segunda fortuna del país, con un capital valorado en 1.800 millones de euros. (Peregil, 2018, p.1)

Los medios de comunicación convencionales al comienzo de la campaña del boicot guardaron silencio. Ninguno mencionó la campaña hasta que creció su repercusión en el ciberespacio y, por ende, tuvo consecuencias en los beneficios económicos de las empresas boicoteadas (Masbah, 2018). En ese momento los miembros del gobierno se vieron en la tesitura de debilitar la campaña con sus declaraciones, como la del director de Danone que tildó a los boicoteadores de «traidores a la patria». El ministro de Economía, Mohamed Boussaid, perteneciente al RNI, llamó «enajenados» a los ciberactivistas del boicot. Y el ministro de Agricultura y Pesca, Aziz Ajanouch, desacreditó públicamente la fuerza de las redes sociales al considerar la campaña virtual como un «juego de niños». Mientras tanto, en las redes sociales seguía la batalla al rojo vivo con informaciones y críticas humorísticas hacia los políticos. En una encuesta realizada en mayo 2018 por el centro de estudios de mercado y encuestas de opinión Averty, se señalaba que de las 1.072 personas encuestadas pertenecientes a las doce regiones de Marruecos, el 79,8 \% conocieron la campaña de boicot a través de las redes sociales, mientras que tan solo el $4,3 \%$ se enteró a través de los medios de comunicación. Así mismo, el 79,8 \% de los encuestados confirmó su apoyo al boicot comercial ${ }^{1}$.

\footnotetext{
${ }^{1}$ Encuesta Averty sobre el boicot de las grandes marcas de consumidores. Disponible en http://cort.as/MxfN consultado el 15/03/2019
} 
Otra declaración que desató críticas y burlas en Facebook fue la del portavoz del Gobierno, Mustafá el Khalfi, cuando advirtió a los ciberactivistas de la persecución legal a todo aquel que difundiera noticias falsas. Entonces, este último subrayó en una rueda de prensa posterior al Consejo de Gobierno, que la divulgación de «informaciones erróneas» está castigada por la ley, concretamente por el Código de Prensa (EFE, 2018).

La campaña del boicot tuvo un éxito sin precedentes en Marruecos, pues creó una crisis de Gobierno. Se ha convertido en un movimiento social tecno-político que no cuestiona tan solo los productos de consumo, sino que va resaltando la corrupción sistémica y las desigualdades sociales (Masbah, 2018). La indignación social ha bombardeado Facebook con publicaciones, imágenes, textos y videos sin que hiciera falta trasladarse al espacio público real. Por consiguiente, el boicot ha demostrado que el pueblo es consciente de que los políticos copan monopolio del mercado y ha manifestado cívicamente su indignación por las injusticias y la corrupción del falsario político (Gallien, 2018)

La manera de protestar demuestra un alto grado de madurez en el pueblo marroquí, que se venía poniendo de manifiesto desde la Primavera Árabe, Hirak El Rif y las movilizaciones de los mineros de Yerada. Los arrestos que siguieron a las manifestaciones en el Rif y Yerada explican la migración de la protesta de la calle a la web. Al boicotear un producto, los usuarios de Internet ejercen el derecho de denunciar sin preocuparse ni arriesgarse como fue el desafortunado destino de algunos activistas de Hirak Rif y de Yerada (Sin autor, 2018). Por lo tanto, la caída de las ventas de las empresas boicoteadas puso de relieve su éxito inédito, tal y como se desprende de la encuesta realizada por el periódico marroquí L'Economiste (De la Cal, 2018), el 42 \% de la población marroquí estaba apoyando este boicot cuya principal empresa afectada era Central Danone, pues el 82 \% de sus consumidores habían decidido dejar de comprar sus productos.

En general, la campaña tecno-política del boicot ha devuelto la confianza al pueblo marroquí convirtiéndolo en el protagonista del cambio social. Esta movilización ha demostrado el grado de conciencia política entre los jóvenes y su disposición para desempeñar un papel eficaz en la preparación para el cambio. Las ausencias de actores o líderes políticos han permitido a los indignados vencer el miedo y aprender a negociar y dialogar con los representantes del Gobierno sin intermediarios. Internet se ha convertido en el principal soporte de esta movilización. Dentro de este mundo virtual, los ciberactivistas reclamaron sus demandas, debatieron su derecho a reivindicar y prepararon a los usuarios de manera psicológica para reforzar su entusiasmo. El boicot de los productos de consumo es una de las armas pacíficas que expresa la conciencia de la sociedad y la unión de la voluntad de sus grupos para cambiar los desequilibrios económicos producidos por la elite del poder.

\section{EL ALCANCE DE LA INVESTIGACIÓN}

En este estudio se realiza un análisis cuantitativo de las redes sociales durante la campaña del boicot comercial del 2018, especialmente Facebook, que es una plataforma social con un uso más fácil y de mayor alcance entre la población marroquí que Twitter que es empleado por una población reducida y más bien intelectual. Por esta razón Facebook se ha convertido en una herramienta estrella en el mundo árabe. Según el informe del Arab Social Media Report (ASMR), que analiza la penetración de los medios sociales en 22 países árabes, que engloban a 400 millones de habitantes, destaca la presencia de las redes sociales entre los jóvenes (un 64 $\%$ de los usuarios son menores de 30 años). Es más, Facebook es la red social que se lleva la palma en toda la región: 156 millones de usuarios a comienzos de 2017, cuando en la misma fecha de 2016 eran 115. Así pues, en Marruecos, concretamente en 2017, Facebook contaba con 16.477.712 usuarios y con una tasa de penetración del 51 \% de la región. En 2016 la cifra 
de usuarios era inferior, y que rondaba los 4.897.320. Es decir, la tasa de los usuarios del Facebook se encuentra en un considerable aumento (Blanco, 2017).

Así pues, retomando el asunto de la metodología aplicada en este estudio, el análisis de contenido trata de descomponer el mensaje tecno-comunicativo publicado en Facebook durante la campaña del boicot comercial. El análisis cuantitativo es una de las técnicas de investigación más importantes de las Ciencias Sociales, que procura comprender los datos, no como un conjunto de conocimientos físicos, sino como fenómenos simbólicos con los que se puede abordar un análisis directo. En este sentido, el marco de referencia de nuestra investigación tiene tres finalidades: descriptiva, analítica y metodológica.

El corpus de análisis de nuestro estudio abarca 150 publicaciones, seleccionadas de manera aleatoria a partir de los grupos de Facebook que abordan la temática de la campaña del boicot comercial desde el 20 de abril a finales de agosto del 2018. Dicha campaña culminó con un éxito considerable al convertirse en un hecho inédito en Marruecos. Los grupos seleccionados son los siguientes: 1. "\#Boicoteamos (Moukatioun)», 2. "\#DéjalaQueSeAgrie (Khalih Yreb)», 3. «\#CampañaDelBoicotContraLaCarestíaYEIMonopolio (Hamlat moukatioun dida al ghalae wa al ihtikar)», 4. "\#BoicoteamosParaSiempre (Moukatiouna ila labad)" 5. "\#NoCallamos, boicoteamos (Masakitinch moukatioun)», 6. "\#ElReinoDeEnajenadosDignos (Mamlakat madaouikh al kiram)» 7«\#TodosBoicoteamos (Kolona moukatioun)».

Hemos tomado como referencia en este estudio las teorías de Krippendorff (1990) y de Berelson (1952, p. 17) en cuanto a la consideración del análisis de contenido como "una técnica de investigación de la descripción objetiva, sistemática y cuantitativa del contenido manifiesto de las comunicaciones que tiene por objeto interpretar". Es decir, a partir de ciertos datos, se formulan inferencias reproducibles y válidas que puedan aplicarse a su contexto. Puesto que formular inferencias es una de las tareas primordiales en este análisis, estas se manifiestan a partir de los datos relacionados con el contexto del objeto de estudio, por lo tanto, a través de este proceso se reconocen los datos como simbólicos facilitadores de la información clave y necesaria.

En nuestra investigación las técnicas para elaborar, registrar y tratar datos de análisis de contenidos se han basado en la normalización de los procesamientos de análisis a través de sus protocolos, en esta ocasión concretamente la ficha de análisis, que es un instrumento de guía o plantilla para el registro de datos. Por consiguiente, lo que resulta del tratamiento de datos se corresponde con la fase de exploración a partir de las técnicas basadas en software informático Microsoft Excel. Introducir procedimientos informáticos en el manejo y tratamiento de datos ha permitido a esta metodología adquirir mayor solidez.

Para la formulación y diseño de esta técnica es importante partir de las hipótesis planteadas y de los objetivos marcados en la introducción, con el fin de definir y establecer una muestra representativa de un determinado corpus seleccionado en pasos relevantes para reflejar la exhaustividad, la uniformidad y la coherencia:

1. Delimitar el objeto de estudio de la investigación: Campaña del boicot comercial 2018.

2. Consultar y explorar las páginas y los grupos de Facebook: se han escogido $\mathbf{1 5 0}$ publicaciones calculando el tamaño de la muestra a partir de un nivel de confianza del $95 \%$ y un error de $\pm 5,5$.

3. Definir los criterios en unidades de análisis: seleccionar de manera aleatoria los grupos, así como las publicaciones de mayor impacto correspondientes a nuestro objeto de estudio.

4. Alcanzar la coherencia entre el objeto de estudio, hipótesis y los objetivos mencionados anteriormente. 
Es más, se han establecido y se han definido las categorías que representan las variables de la investigación, se han seleccionado los codificadores elaborando las hojas de codificación, se ha efectuado la codificación contando las frecuencias de repetición de las categorías y, por último, se ha realizado un escrupuloso análisis estadístico para obtener datos descriptivos a través de la elaboración de gráficos que nos permitan sacar las conclusiones que nos llevaran a afirmar o refutar las hipótesis planteadas anteriormente.

En cuanto al proceso de categorización, se ha realizado la clasificación de los elementos de manera estructural: un conjunto por diferenciación tras la agrupación de manera analógica. Nuestra categorización está completamente relacionada y matizada con nuestro objeto de estudio, así que se ha adoptado un criterio de categorías semánticas o temáticas, es decir, tras las primeras lecturas de las publicaciones del estudio, se han seleccionado los temas de mayor repetición y repercusión y se han agrupado bajo una determinada denominación, tal como aparece en la siguiente ficha de análisis.

\section{Tabla 1}

Plantilla de análisis

\begin{tabular}{|l|l|}
\hline \multicolumn{1}{|c|}{ VARIABLES } & \multicolumn{1}{|c|}{ CATEGORIAS } \\
\hline V1. Número de registro & Modelo \\
\hline V2. Soporte: Facebook & $\begin{array}{l}\text { 1. Boicoteamos (Moukatioun) } \\
\text { 2. Déjala que se agrie (Khalih Yreb) } \\
\text { 3. Los marroquíes del mundo por el boicot (Al magharibat al } \\
\text { alam min ajli al moukataa) } \\
\text { 4. Campaña del boicot contra la carestía y el monopolio } \\
\text { (Hamlat mokayoin dida al ghalae wa al ihtikar) }\end{array}$ \\
& $\begin{array}{l}\text { 5. No callamos, boicoteamos (Masakitinch moukatioun) } \\
\text { 6. El reino de «enajenados» dignos (Mamlakat madaouikh al } \\
\text { kiram) }\end{array}$ \\
\hline 7. Todos boicoteamos (Kolona moukatioun)
\end{tabular}




\begin{tabular}{|l|l|}
\hline v.7. Género de las temáticas & 1. Contenido satírico \\
& 2. Contenido emocional \\
& 3. Contenido político \\
& 4. Contenido social \\
5. Contenido informativo \\
\hline V. Temáticas dominantes & 1. Justicia social \\
& 2. Las empresas: combustibles Afriquia, leche Centrale, agua \\
& Sidi Ali. \\
3. Boicot \\
4. Campaña \\
5. Interacción \\
6. Activistas \\
7. Resistencia \\
8. Aziz Akhannouch (El ministro de la agricultura y pesca \\
marítima) \\
9. Mustafa El khalfi (Ministro de comunicación, portavoz del \\
gobierno) \\
10. Los productos comerciales denunciados \\
11. La carestía de vida \\
12. Makhzen \\
13. Subida de precios \\
14. La pobreza del pueblo \\
15. La brecha social y económica \\
16. Corrupción \\
17. Otros políticos \\
\hline
\end{tabular}

Fuente: elaboración propia.

\section{ANÁLISIS CUANTITATIVO DE LA INVESTIGACIÓN: RESULTADOS}

El corpus de estudio se compone de 150 publicaciones seleccionadas aleatoriamente y pertenecientes a 7 grupos de Facebook buscados a través del término clave «Boicoteamos». Este concepto se hizo viral en la campaña del boicot comercial iniciada de forma continua por ciberactivistas anónimos el 20 de abril del 2018 y que debido a la creciente influencia de sus mensajes difundidos por Facebook, tuvo una respuesta crítica por parte del Gobierno. En concreto nos referimos a Moustafa el Khalfi, perteneciente al Partido Justicia y Desarrollo (PJD), y Aziz Ajanouch, militante del RNI (partido de Reagrupamiento Nacional Independiente), satirizados por las redes sociales, especialmente cuando el portavoz del gobierno, Mustafá el Khalfi, anunció públicamente de forma intimidatoria la persecución legal contra quienes difundían noticias falsas, fake news, sobre la campaña del boicot. 


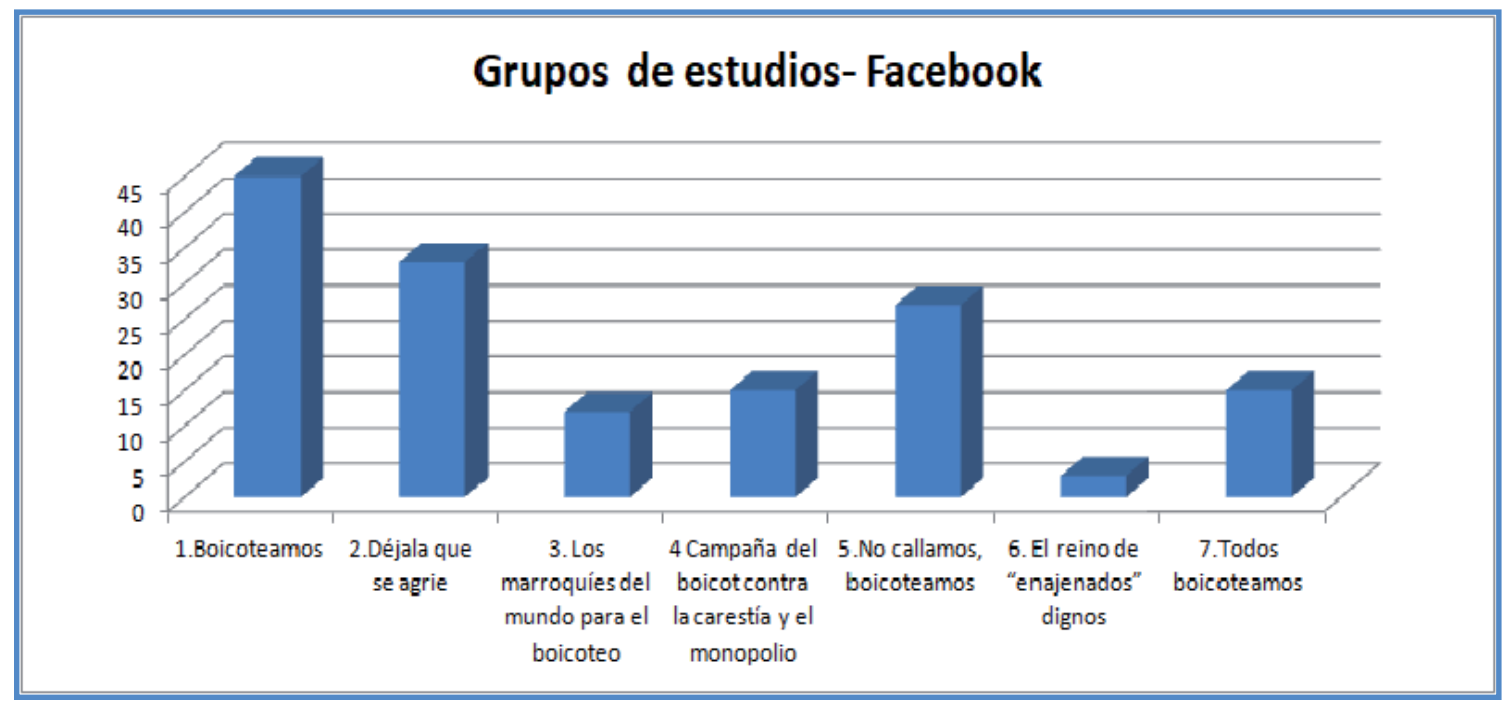

Figura 1. Grupos de estudio: Facebook

Fuente: elaboración propia.

En el gráfico anterior se observa que el grupo «\#boicoteamos» ha registrado el mayor número de publicaciones en la campaña del boicot, unas 45 del total de 150. Es seguido por el grupo «\#DéjalaQueSeAgrie» con unas 33 publicaciones y por el grupo «\#NoCallamos,boicoteamos» con unas 27, mientras que el grupo "\#EIReinoDe"enajenados" dignos» marcaron una cifra muy inferior con 3 publicaciones.

Lo que se deduce de esta distribución es que el grupo donde se menciona el término «boicoteamos» ha tenido mayor presencia, peso e influencia en Facebook debido a que aparece la palabra clave de la campaña mientras que el grupo "\#EIReinoDeEnajenados"», en el que encontramos la palabra «enajenados» (mdaouikh, en árabe) no ha tenido el protagonismo en el periodo analizado en comparación con los otros grupos estudiados.

Cabe aclarar que el término "enajenados» fue usado por el ministro de Economía, perteneciente al RNI, Mohamed Boussaid el martes 24 de abril para referirse a los indignados y a los ciberactivistas del boicot, ya que, según el ministro Boussaid, estos últimos frenan el desarrollo empresarial del país y causan desempleo a los ciudadanos, por lo tanto, en vez de animar la economía, la estarían destruyendo. El hecho de formarse grupos en Facebook bajo términos que son despectivos, como «enajenados», sacados de los discursos de los políticos o empresarios, es una clara protesta ciberactivista de los indignados. 


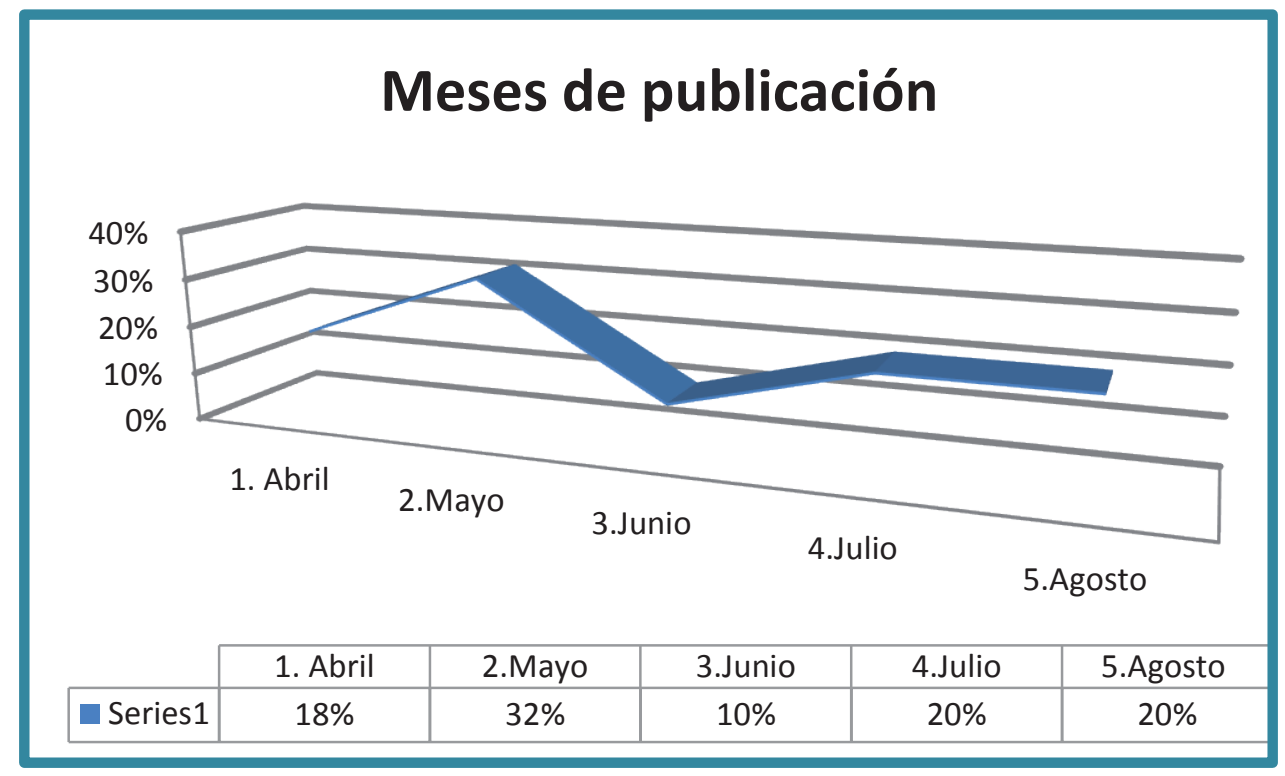

\section{Figura 2. Meses de publicación}

Fuente: elaboración propia.

Según la exposición de la figura 2, las publicaciones de los grupos de Facebook analizadas han registrado su mayor porcentaje en el mes de mayo con un $32 \%$, seguido por julio y agosto con un $20 \%$ respectivamente, y en tercer lugar el mes de abril con el $18 \%$ del total de las 150 publicaciones mientras que el mes de junio registró un porcentaje inferior del $10 \%$ en comparación con el resto de los meses. Estos datos se interpretan en relación con el desarrollo de la campaña, ya que el 20 de abril surgió el llamamiento anónimo al boicot, por el cual podemos resaltar que, como es lógico, el mayor porcentaje de publicaciones se encuentra en el mes abril y no en el de mayo, puesto que el conteo de publicaciones empezó el día 20 de ese mes.

En general, los mayores porcentajes se ubican en abril y mayo, al darse en ellos el comienzo de la campaña del boicot a través de las páginas de Facebook con la meta de boicotear los productos denunciados. La respuesta del ministro de Economía, Mohamed Busaid, hacia los ciberactivistas y boicoteadores ha sido duramente criticada, sobre todo al calificarlos de "enajenados", (en árabe madaouikh) y también, la reacción de Adil Benkirane, directivo de Centrale Danone, quien los tildó de "traidores». Ambas contestaciones han producido el efecto contrario al que buscaban, ya que han movilizado con gran velocidad las páginas de Facebook, especialmente en el cuarto y quinto mes. 


\section{Número de seguidores}

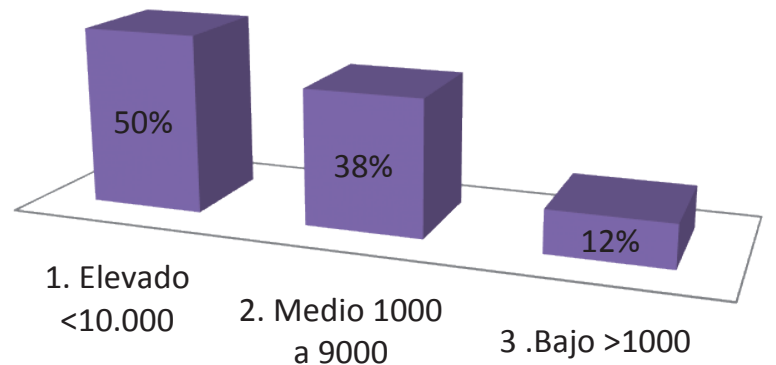

Figura 3. Número de seguidores

Fuente: elaboración propia.

Durante la campaña del boicot el impacto del ciberactivismo desempeñó un papel considerable, que se vio reflejado en el nivel de repercusión en la opinión pública, que se tradujo inmediatamente en una acción eficaz y contundente al dejar de adquirir los productos de esas compañías. Para medir el impacto es imprescindible recurrir al porcentaje de usuarios que formaron parte de estos grupos de Facebook analizados. De hecho, encontramos que el $50 \%$ de estas páginas contaron con un número elevado de seguidores, es decir más de 10.000 usuarios, seguido por el $38 \%$ cuyo promedio de internautas que oscila entre 900 y 1.000 usuarios, mientras que tan solo el $12 \%$ de las mismas han registrado un número inferior a los 1.000 seguidores.

Estos datos evidencian el elevado impacto del uso de Facebook en este periodo de estudio, ya que según el informe realizado por los especialistas en redes sociales We Are Social, el número de usuarios activos en Marruecos fue de aproximadamente de 16 millones en enero de 2018 y poco más del $44 \%$ de los marroquíes tienen cuentas en esta red social. Los internautas en el ciberespacio registraron un aumento del 14\% en comparación con enero de $2017^{2}$.

Otro dato que revelan estas cifras es que los usuarios se refugian en el ciberespacio, que se convierte en un mecanismo de oposición a la autoridad establecida, obviando la preponderancia de la información de los medios convencionales que silencian todas las protestas y que son controlados por el poder gobernante. Es más, permite a los seguidores de estas campañas de protesta interactuar de manera positiva y libre en ese espacio.

\footnotetext{
${ }^{2}$ Informe We are social digital. Disponible en http://cort.as/-IxPV: consultado 05/04/2019
} 


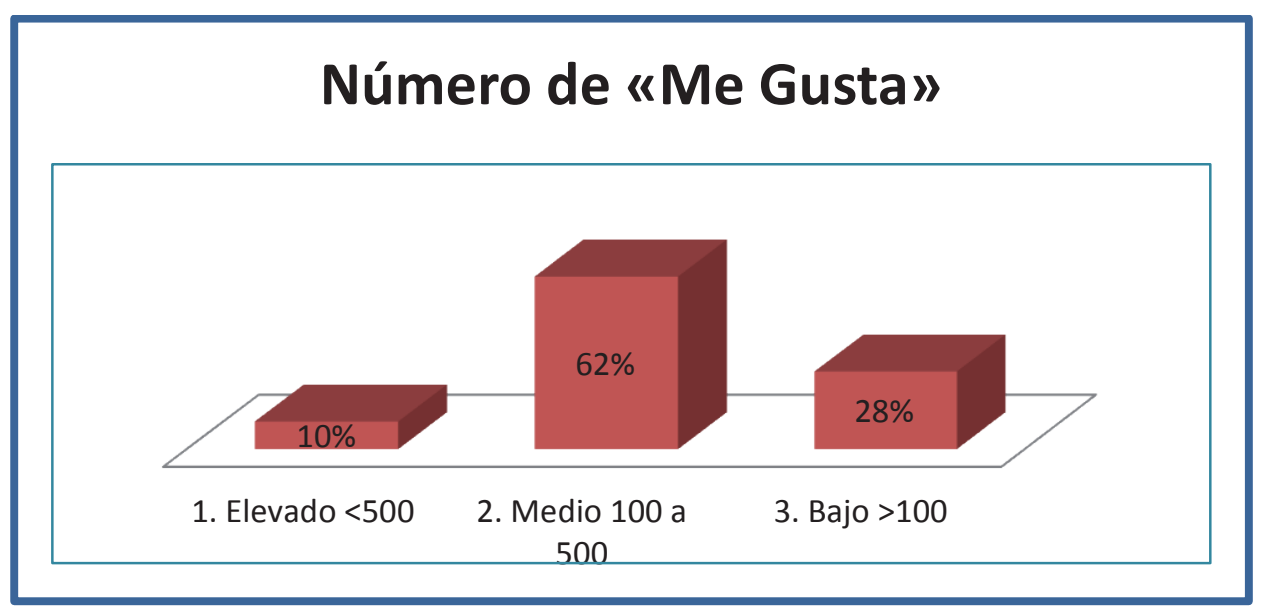

Figura 4. Número de «Me gusta»

Fuente: elaboración propia.

La herramienta habilitada por la red social Facebook "Me gusta», que se describe como una forma de retroalimentación positiva y se conecta con sucesos y/o temas que interesan a los usuarios ${ }^{3}$, también muestra la aprobación y la aceptación de los seguidores al contenido publicado. En este gráfico 4, se muestra el número de usuarios a los que les han gustado los contenidos publicados durante la campaña del boicot y cuya respuesta media oscila entre 100 y 500 likes, es decir, el $62 \%$ de las publicaciones han contado con una aprobación media del contenido.

La aceptación elevada de más de 500 «me gusta» ha registrado tan solo el $10 \%$ del total de 150 publicaciones mientras que el $28 \%$ de las publicaciones han obtenido un número bajo, menos de 500. O sea, un registro elevado revela su grado de influencia en el lector del contenido y también el interés de este, sin embargo, tal y como explica Marc Masip, psicólogo experto en adicciones a las nuevas tecnologías, «puede haber mil intenciones detrás de un me gusta, como en los comportamientos en la vida real, pero finalmente, se van a quedar en dos: o me interesa tu publicación o me interesa llamar tu atención por algún motivo» (Vallés, 2018). Lo que quiero acentuar es que el miedo a la persecución y a interactuar libremente en el ciberespacio afirmando la aprobación hacia un contenido político y social, como el boicot en este caso, ha podido influir a la hora de otorgar la aprobación en público, por eso las publicaciones se han quedado en un número medio de «Me gusta».

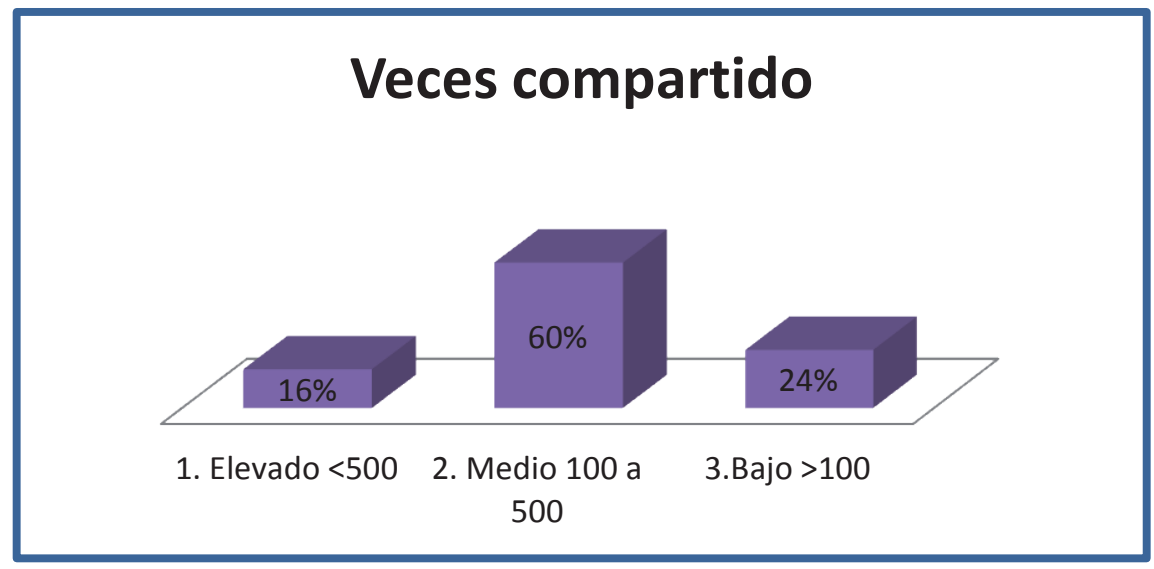

Figura 5. Número de veces compartido

\footnotetext{
${ }^{3}$ «Like». Facebook Help Centre. Consultado el 01 de abril de 2019.
} 
Fuente: elaboración propia.

En el gráfico 5, analizamos casi los mismos datos estadísticos del gráfico 4. Encontramos que el $60 \%$ de las publicaciones han registrado un número de "compartir» medio que oscila entre 100 y 500 , seguido por $24 \%$ que ha obtenido una cifra por debajo de 100 mientras que tan solo el $16 \%$ de las publicaciones ha registrado un número elevado de «compartir».

Estos datos indican el miedo de compartir las publicaciones por más que hayan sido seguidas por los internautas. Compartir contenido da lugar a mayor presencia en la red para difundir la campaña de boicot. La teoría de la aprobación está presente a la hora de compartir contenido, así como el temor a la persecución digital de los que apoyaran el boicot tras ser calificada negativamente la campaña por las autoridades gubernamentales, que la consideraba basada en nociones equivocadas e informaciones falsas. Por lo tanto, el hecho de compartir contenido ha repercutido, sin lugar a dudas, en el número medio que ha registrado el gráfico.

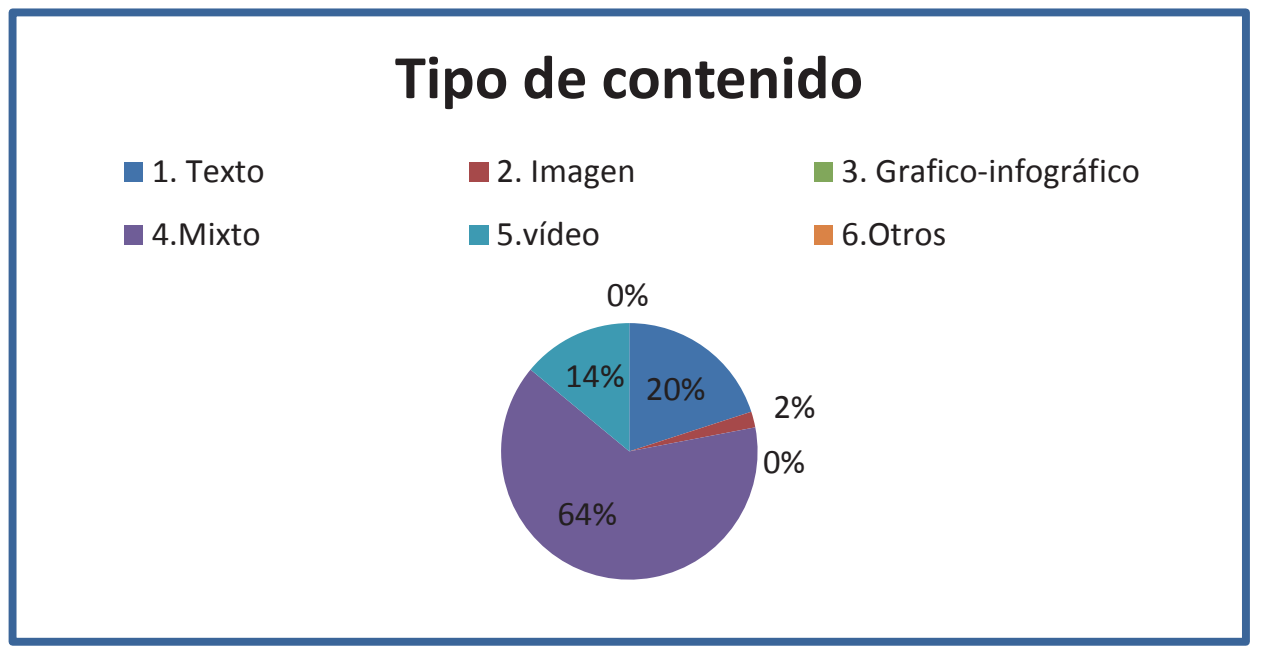

Figura 6. Tipo de contenido

Fuente: elaboración propia.

En cuanto al tipo de contenido que ha tenido mayor protagonismo es el que hemos denominado "mixto», es decir, la combinación entre imagen-texto o vídeo-texto. El componente mixto ha registrado un $64 \%$ del total de las 150 publicaciones, seguido por vídeos con un $20 \%$ y texto un $14 \%$. Estos porcentajes elevados señalan que el tipo de contenido en que se mezclan imagen, vídeo y texto ha tenido mayor influencia en el usuario, ya que por naturaleza Facebook es una herramienta visual y viral que pretende influir para generar interacción con los usuarios y mayor implicación. Por eso los indignados optaron por esta herramienta para llevar a cabo la campaña del boicot. 


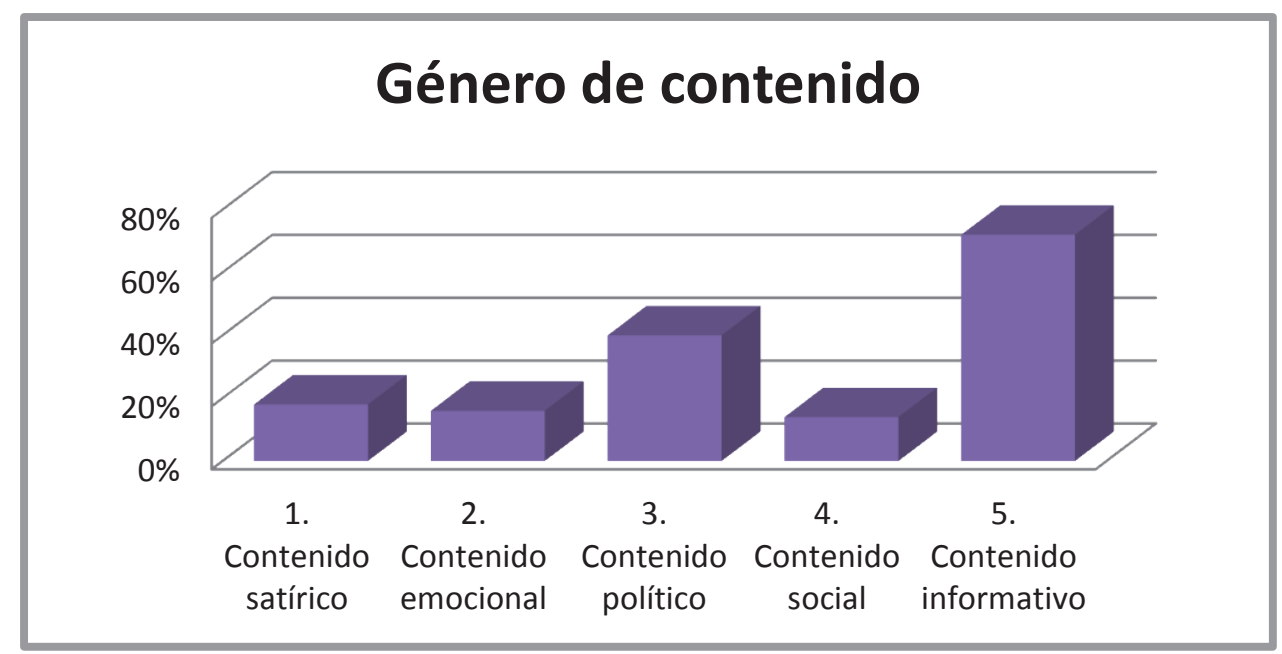

\section{Figura 7. Género de contenido}

Fuente: elaboración propia.

En la figura 7, se muestra que el contenido informativo ha alcanzado el mayor porcentaje, un $72 \%$ de publicación, seguido por el político con un $40 \%$ y por el satírico, que registra un $18 \%$ del total de publicaciones. Los contenidos emocionales y sociales han obtenido un número inferior en comparación con los demás.

Estos datos estadísticos se explican por la ausencia de información por parte de los medios de comunicación convencionales: la demanda de información fidedigna y la necesidad de dotar a los usuarios de contenido informativo se ha reflejado en el alto porcentaje de este tipo de contenidos. La desinformación es una herramienta que usa el gobierno para dejar al público carente de noticias veraces, por lo tanto, en cada publicación, lo que hacían los ciberactivistas era desmantelar la manipulación de la realidad social vivida en Marruecos con la intención de informar sobre lo que verdaderamente estaba ocurriendo y al mismo tiempo alcanzar una repercusión en la opinión pública.

Al tratarse de una campaña del boicot de productos cuyas compañías pertenecen al poder político, no es sorprendente que el resultado de los contenidos políticos y satíricos ocupara una posición marginal. Es manifiesto que el contenido satírico permite a los internautas expresar libremente su indignación hacia algún asunto de manera irónica, con lo que llegan más a la opinión pública. 


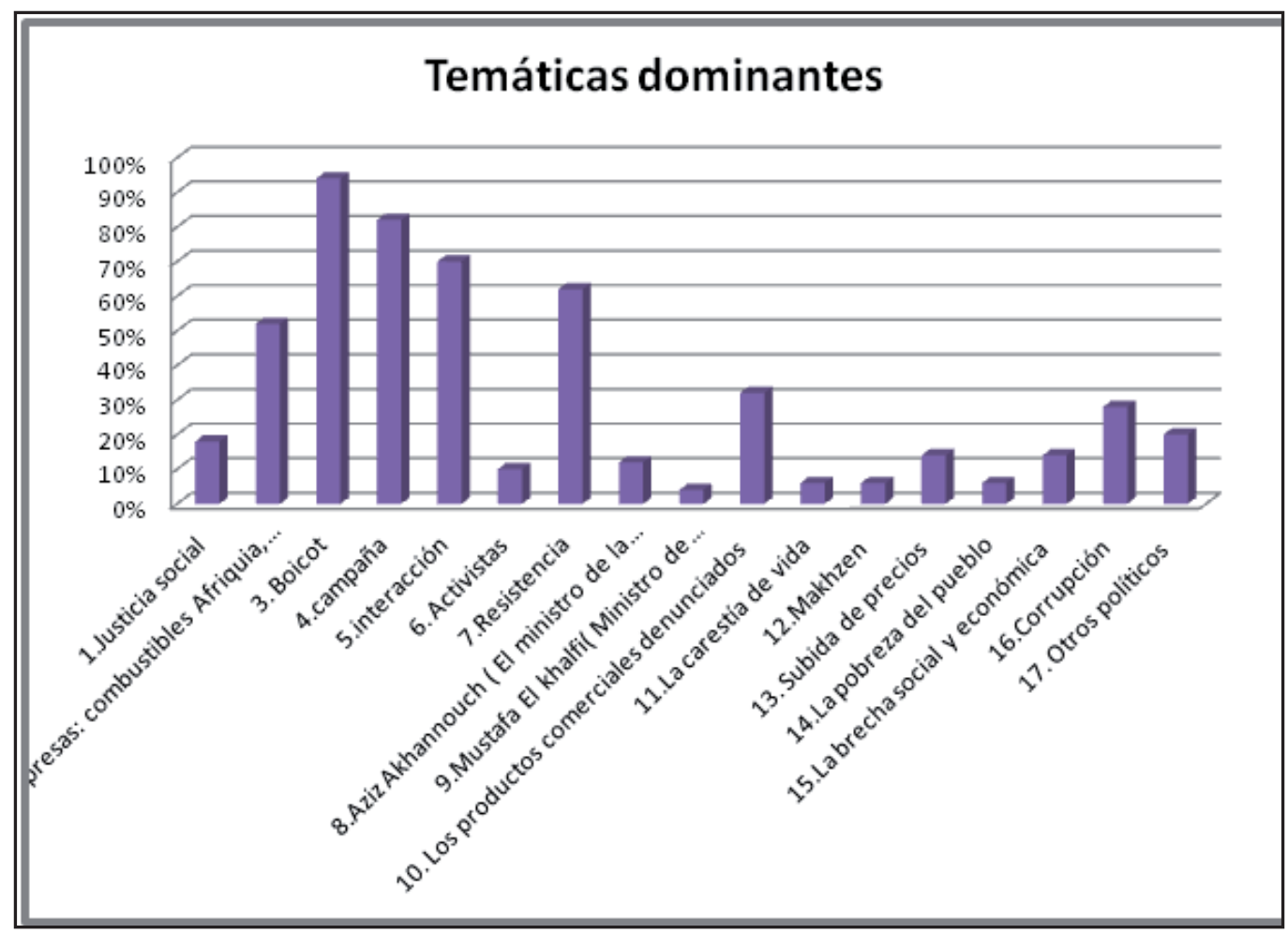

Figura 8. Temáticas dominantes

Fuente: elaboración propia.

En el gráfico 8 se exponen las temáticas dominantes que han sido abordadas por los grupos de Facebook analizados durante la campaña del boicot. Las más influyentes y repetitivas son las relacionadas con el "Boicot» y la "Campaña» que obtuvieron un porcentaje mayor, de $94 \%$ y $82 \%$ respectivamente del total. Las temáticas "Interacción» y "Resistencia» han sido abordadas también con bastante frecuencia con unos porcentajes que se consideran elevados: un $70 \%$ para el primer concepto y $62 \%$ para el segundo.

El siguiente eje temático es el relacionado con «las empresas: combustibles Afriquia, leche Centrale, agua Sidi Ali», con un porcentaje 52\% mientras que el de «Productos comerciales denunciados» ocupó un 32\% de las publicaciones. El eje «Corrupción» ha tenido una presencia de un $28 \%$, "Justicia social» de un $18 \%$ y "subida de precios» de $14 \%$. Sin embargo, las temáticas correspondientes al ministro de Comunicación, Mustafá El Khalfi, han registrado un porcentaje inferior al $4 \%$ en comparación con las de Aziz Akhannouch que han alcanzado un $12 \%$. Criticado satíricamente por los ciberactivistas ya que es uno de los propietarios de las empresas boicoteadas y realizó además incendiarias declaraciones ante los medios de comunicación: "La campaña de boicot no afectará a la venta de estos productos en el mercado. Es una campaña virtual, no va a afectar a la subsistencia de 470.000 personas que trabajan en el sector lácteo. Esto no es un juego [de niños]. Quienes quieran jugar, solo tienen que irse a otra parte" (Peregil, 2018).

La campaña del boicot, su interacción, su resistencia, las empresas denunciadas y sus correspondientes productos, la corrupción y la justicia social son temáticas claves que determinan el conocimiento de los hechos y, así mismo, se posicionan para tomar una acción al respecto. 


\section{CONCLUSIONES GENERALES}

En este análisis de contenido, realizado sobre las practicas tecno-comunicativas en especial la red social Facebook, en el que se han analizado 150 muestras de publicaciones producidas durante la campaña del boicot comercial de 2018, ha conducido a confirmar las hipótesis planteadas al inicio de este estudio. Los objetivos marcados al principio se han visto cumplidos a lo largo de este análisis, cuya meta principal consistía en analizar las prácticas tecnocomunicativas producidas durante la campaña del boicot comercial.

En efecto, con el resultado conseguido hemos de resaltar que, de los 7 grupos de Facebook analizados, los más influyentes y los que han registrado mayores publicaciones han sido «\#boicoteamos» y «\#DéjalaQueSeAgrie». El grupo «boicoteamos» ha tenido mayor presencia, peso e influencia en Facebook debido al uso del término clave en la campaña y a la cantidad de información divulgada al respecto. El inicio de la campaña del boicot condicionó los meses de abril y mayo con porcentajes elevados de publicaciones, $18 \%$ y $32 \%$ respectivamente. Debido a que, circunstancialmente, los mencionados porcentajes coinciden en el tiempo con las declaraciones provocadoras de unos miembros del Gobierno, al calificar a los ciberactivistas despectivamente con el uso del término "enajenados» (madaouikh) o con la calificación del directivo de la empresa Centrale Danone de "traidores», hemos de concluir que estas respuestas no hicieron más que movilizar y encender a los internautas.

El impacto de la campaña del boicot se ha traducido fundamentalmente en su propio éxito, pues obligó a las empresas a bajar los precios de consumo a pesar de los intentos de descrédito de la campaña. El impacto se refleja especialmente, por un lado, en el número de seguidores de los grupos analizados, que registraron más de 10.000 usuarios mientras que tan solo el $12 \%$ de dichas páginas, han registrado un número inferior a los 1.000 seguidores, y por otro lado, en la aprobación y la aceptación de los seguidores del contenido publicado mediante los elementos "Me gusta» y "veces compartido", que han registrado un porcentaje medio del $62 \%$ y del $60 \%$ respectivamente. No obstante, esta aprobación media se puede atribuir al temor a la persecución de los ciberactivistas, sobre todo tras la declaración oficial del portavoz del gobierno Mustafá el Khalfi, que afirmó en los medios de comunicación la persecución de cualquier ciberactivista por difusión de noticias falsas que, según él, repercuten negativamente en los beneficios económicos del país.

En tal sentido, los tipos de contenido explotados en las publicaciones de Facebook imagen, vídeo y texto han tenido mayor peso en el usuario, ya que la campaña pretende influir en el público para generar interacción y una mayor implicación. Como estrategia tecnocomunicativa, los ciberactivistas apostaron por el contenido informativo, político y satírico. Mantener informados a sus seguidores era una de sus técnicas primordiales, ya que contar lo sucedido en cada momento es la demanda que anhela el pueblo, por eso el contenido informativo ha alcanzado el mayor porcentaje, un $72 \%$ de publicación. Así pues, estos datos estadísticos se explican claramente por la ausencia de información por parte de los medios de comunicación convencionales. Demuestra la necesidad de estar informados de forma veraz y de dotar a los usuarios de contenido informativo fiable que se ha reflejado en el número alto de este tipo de contenidos.

En cuanto a las temáticas más influyentes y repetitivas analizadas son las relacionadas con el «Boicot» y la "Campaña», así como con «Interacción» y "Resistencia». La interacción es la intención clave de la campaña del boicot para que se expandiera por toda la comunidad digital. La resistencia es un concepto que ha sido usado en las movilizaciones sociales que se han sucedido desde la Primavera Árabe. Es una resistencia ante el poder político que monopoliza el mercado económico del país, una resistencia hacia los que quieren romper la campaña y llevarla al fracaso con la manipulación mediática de los medios convencionales que intentan 
presentar a los ciberactivistas boicoteadores como jóvenes traidores que manejan las redes sociales con irresponsabilidad ciudadana.

En resumidas cuentas, se puede afirmar que los boicoteadores han tenido éxito a través de las redes sociales a la hora de crear otros medios de comunicación y formar una nueva doctrina relacional, o un patrón amplio y sólido de comunicación a través de medios que son difíciles de controlar. Se ha convertido en una realidad real y no virtual. Por lo tanto, las redes sociales hicieron surgir un nuevo fenómeno, una nueva interacción social, que con su capacidad comunicativa estableció un nuevo espacio alternativo. La creación de páginas que tratan las noticias de una manera simple y fácil y producir discursos reales reivindicativos ha sido un gran acierto. De esta forma han podido ganar popularidad para expresar la voluntad del pueblo en este espacio virtual caracterizado por la libertad de expresión entre diferentes ideas y opiniones. Así pues, a través de Internet, se organizaron y se estructuraron, por eso fue, es y sigue siendo un pilar de suma importancia desde los inicios de la Primavera Árabe, cuando actuó como intermediario y nexo de conexión entre los cibernautas y los indignados. Las nuevas tecnologías consiguieron aumentar el nivel de comunicación entre los ciudadanos sin importar ni el tiempo ni el espacio, lo que convirtió la campaña del boicot en una inédita movilización.

A lo largo de este estudio, algunas de las limitaciones afrontadas han sido las dificultades para acceder al grupo de Facebook de los boicoteadores para analizar los mensajes difundidos. No se han podido comparar las publicaciones de los opositores al boicot a nivel individual, ni los grupos contrarios a la campaña. Tampoco se han podido estudiar otras prácticas tecnocomunicativas, como Twitter y YouTube. Por lo tanto, para futuras investigaciones, sería de gran interés abordar los aspectos mencionados anteriormente para enriquecer aún más este estudio, ya que el ciberactivismo ha sido una práctica fundamental para las movilizaciones sociales surgidas en los países árabes, donde la libertad de expresión está sujeta a rigurosas restricciones.

\section{Referencias}

Abu-Tarbush, J. (2011). El cambio Político en el mundo árabe. Colección de estudios internacionales. Número 9.

Almirat, H. (2009). Talk Morocco [Comentario de blog]. http:// www.talkmorocco.net/about/

Amirah Fernández, H. (2015). La verdadera "excepción árabe". Real Instituto Elcano. https://goo.gl/noMZUn

Benítez-Eyzaguirre, L. (2015). Videoactivismo en Marruecos. El movimiento 20 de febrero. http://cort.as/-Iwsi

Berelson, B. (1952). Content Analysis in Communication Researches. Glencoe III, Free Press.

BetancourT, V. (2011). Ciberactivismo: ¿Utopía o posibilidad de resistencia y transformación en la era de la sociedad desinformada de la información? Chasqui, 116, 94-97.https://goo.gl/BuUyFH

Blanco, J.M. (2017, 29 de agosto). Radiografía de las redes sociales en el mundo árabe: entre el auge y el bloqueo. El Confidencial. http://cort.as/-Iwtg

Boaziz, F, Z. (2018, 1 de mayo). Un boicot comercial se vuelve campaña política contra el sistema en Marruecos. El Confidencial. http://cort.as/-IxXv

Boudal, Y. (2018, 1 de agosto). Morocco's King Mohammed sacks minister after urging action on economy. Reuters. http://cort.as/-N6p6

Brouksy, O. (2018). Morocco: His Majesty's Bosses Boycotted, orientxxi. http://cort.as/-N6rK.

Buamama, A. y Khaira, B. (2015). Achabakat ijtima3iya wa tahaoulat asiyasiya fi al ala, arabi [Redes sociales y transformaciones políticas en el mundo árabe]. http://cort.as/-MQOI 
Caballero Quemades, F. y Monroic Climent, V. (2004). Información y conocimiento en la era de Internet. Editorial Marfil.

Castells, M. (2000). La era de la información. La sociedad red (vol. I). Alianza Editorial.

Castells, M. (2009). Comunicación y poder. Alianza Editorial.

Castells, M. (2012). Redes de indignación y esperanza. Alianza.

Catala, S. (2018). Marruecos: un boicot contra la austeridad y la corrupción. El Salto. http://cort.as/-IxYq

Dahlgren, P. (2011). Jóvenes y participación política. Los medios en la Red y la cultura cívica. Telos, 89

De la cal, L. (2018, 6 de junio). Un boicot a tres grandes marcas desestabiliza al gobierno marroquí. EI Mundo. http://cort.as/-Iwt3

Edixela, B. (2020). Ciberactivismo, ejercicio de la ciudadanía y participación política en Internet. https://bit.ly/33nAhsQ

Espiritusanto, O y Gonzalo Rodríguez, P (2011). Periodismo ciudadano: evolución positiva de la comunicación. Ariel. Colección Fundación Telefónica

Fernández Prados, J, S. (2012). Ciberactivismo: conceptualización, hipótesis y medida. ARBOR Ciencia, Pensamiento y Cultura Vol. 188 - 756.

Fernandez-Planells, A, y Linares, J. (2015) Comunicación para el cambio social: uso de los dispositivos móviles y de la web social como canal de información y participación en el $15 \mathrm{M}$. Congreso \#comunicambio.

Flores, V, J. Y Arrutl, A.M. (2010). Ciberperiodismo. Limusa.

Gallien, M. (2018). Is Morocco's boycott the future of political resistance in north Africa? Middle East Eye. http://cort.as/-N6qD

Ganimi, M. (2018). Tahdidat hokoumiya baada hamlate moukataa ghair masbouka bel maghreb [Amenazas del gobierno, tras la campaña del boicot sin precedentes en Marruecos]. Al Arabia. http://cort.as/-Ixib

González-Lizárraga, M.G.; Becerra-Traver, M.T., \& Yánez-Díaz, M. B. (2016). Ciberactivismo: nueva forma de participación para estudiantes universitarios [Cyberactivism: A new form of participation for University Students]. Comunicar, 46(XXIV), 47-54.

Jedidi, J. (2018). "Marruecos, Aquí, Ahora” Misterioso llamamiento a boicotear productos marroquíes. Info marruecos.ma. http://cort.as/-Ixaw

Krippendorff, K. (1990). Metodología de análisis de contenido. Teoría y práctica. Paidós.

Lasswell, Harold, D. (1985). Estructura y función de la comunicación en la sociedad. En sociología de la comunicación de masas, II. Estructura, funciones y efectos, de Miquel de Moragas (editor), Gustavo Gili.

Lopez, S. (2018, 24 de junio). Los Observadores: Boicot a productos caros en Marruecos. France24. http://cort.as/-IxZy

Masbah, M. (2018). Let it Spoil!”: Morocco's Boycott and the Empowerment of 'Regular' Citizen. https://mipa.institute/6216

Otman, D. (2016). Than Mo: jaras indar linidam bel maghrib [Tahn Mo: Campana de alarma para el sistema en Marruecos]. Idaat. http://cort.as/-Iws|

Ouled, Y. (2018). Represión en el Rif y nuevos "Hirak" en Marruecos por una vida digna. El Salto https://n9.cl/dugn7

Parejo Fernández, M. (2015). Cambio y límites en Marruecos: propuestas de reforma constitucional sobre el Gobierno. Revista CIDOB d'Afers Internacionals n.109, p. 23-44

Peregil, F. (2017, 23 de abril). El amigo del rey de Marruecos que dobló el brazo a los islamistas. El País. http://cort.as/-Iwsw 
Peregil, F. (2018, 12 de mayo). El boicot en Marruecos a tres marcas se ceba con el ministro más poderoso. El País. http://cort.as/-Iwu5

Peregil, F. (2018, 27 de abril). El ministro más influyente de Marruecos, víctima de un boicot a su empresa. El País. http://cort.as/-Iwt9

Sierra Caballero, F. (2020). Ciberactivismo y nuevos movimientos urbanos: la producción del nuevo espacio público en la política contemporánea. Perspectivas de la comunicación. Online version ISSN 0718-4867.https://bit.ly/3lksAdd

Sin Autor, (2018). El boicot en Marruecos*. Tamaimos. http://cort.as/-Iwtb

Sin Autor, EFE, (2018, 10 de mayo). Marruecos amenaza con perseguir en justicia a promotores de boicot comercial. El Periódico. http://cort.as/-IwtV

Soengas, X. (2013). El papel de Internet y de las redes sociales en las revueltas árabes: una alternativa a la censura de la prensa oficial. http://cort.as/-Iwsc

Tascón, M. y Quintana, y. (2012). Ciberactivismo. Las nuevas revoluciones de las multitudes conectadas. Los Libros de la Catarata.

Tufte, T. (2015). Comunicación para el cambio social. La participación y el empoderamiento como base en el desarrollo mundial. Icaria.

Vallés, R. (2018, 22 de julio). Lo que de verdad esconde un me gusta. La Vanguardia. http://cort.as/-Iwu_

Zairig, R (2018). Social Protest in Morocco: Does Mohammed VI Have a Plan? Middle East Eye. http://cort.as/-N6qe

\section{Semblanza de la autora}

Nasma Irakrak es doctora en Comunicación por la Universidad de Sevilla, especialista en el análisis del discurso periodístico, cambio social y la transición digital en el mundo árabe. Licenciada en Filología Hispánica, máster en Enseñanza del Español como Lengua Extranjera y máster en Comunicación y Cultura. Miembro del grupo de investigación de Comunicación, Cultura y Ciencia de la Universidad de Sevilla. Combina la investigación con su labor profesional en el ámbito de inmigración e interculturalidad. 